\title{
PCC Regimen
}

National Cancer Institute

\section{Source}

National Cancer Institute. PCC Regimen. NCI Thesaurus. Code C37597.

A chemoimmunotherapy regimen consisting of paclitaxel, carboplatin, and cetuximab that can be used for the treatment of squamous cell carcinoma of the head and neck (SCCHN). 